\author{
Jurnal E-Bis (Ekonomi-Bisnis) \\ Vol. 5 No.1 (2021) pp. 55-66 \\ https://jurnal.politeknik-kebumen.ac.id/index.php/E-Bis \\ p-ISSN : 2580-2062 e-ISSN : 2622-3368
}

\title{
Analisis Perbandingan Harga Pokok Produksi Metode Full Costing Dan Variabel Costing Pada CV Gemilang Kencana Wonosobo
}

\author{
Suratno $^{\mathbf{1}^{*}}$, Wakhid Yuliyanto ${ }^{2}$ \\ ${ }^{12}$ Akuntansi/Akuntansi, Politeknik Dharma Patria Kebumen, Indonesia \\ *Email: ardara1969@gmail.com \\ Doi : https://doi.org/10.37339/jurnal e-bis.v5i1.515
}

Diterbitkan oleh Politeknik Dharma Patria Kebumen

\section{Info Artikel}

Diterima :

2021-03-19

Diperbaiki :

2021-04-16

Disetujui :

2021-05-31

\begin{abstract}
ABSTRAK
Tujuan penellitian ini untuk mengetahui dan perbandingan harga pokok produksi metode full costing dan variable costing pada CV Gemilang Kencana untuk tahun 2020. Metode penelitian dengan deskriptif kuantitatif berdasarkan data biaya-biaya produksi dengan menggunakan teknik analisis data Full costing dan Variabel costing. Hasil perhitungan harga pokok produksi full costing untuk tahun 2020 sebesar Rp. 2.069.075.990 dan untuk perhitungan dengan metode variabel costing sebesar Rp. 1.695.253.740. Sedangkan hasil perhitungan harga pokok produksi per kilo dengan metode full costing sebesar $\mathrm{Rp} 15.329 / \mathrm{Kg}$ dan untuk variabel costing sebesar Rp. 12.599/Kg. Dari perhitungan kedua metode tersebut menghasilkan selisih total sebesar Rp. 373.822.250 dan selisih harga sebesar Rp 2.730/Kg.
\end{abstract}

Kata Kunci: Harga Pokok produksi, Full Costing, Variabel Costing

\begin{abstract}
The purpose of this research is to find out and compare the cost of production of the full costing and variable costing methods at CV Gemilang Kencana for 2020. The research method is descriptive quantitative based on data on production costs using data analysis techniques Full costing and variable costing. The results of the calculation of the full costing cost of production for 2020 amounting to $R p$. 2,069,075,990 and for the calculation with the variable costing method of Rp. 1,695,253,740. Meanwhile, the calculation of the cost of goods manufactured per kilo using the full costing method is Rp. 15,329 / Kg and for variable costing is Rp. 12,599 / Kg. From the calculation of the two methods, the total difference is Rp. 373,822,250 and the difference in price is Rp. 2,730/ Kg.
\end{abstract}

Keywords: write down 3-5 keywords related to the content of the paper 


\section{PENDAHULUAN}

Dunia usaha saat ini menunjukkan trend positif. Namun pelaku usaha tetap dituntut kreatif dan inofatif, sehingga usahanya dapat bersaing di era teknologi yang sangat pesat pada saat ini. Upaya perusahaan perusahaan dalam mencari laba harus terus ditingkatkan agar tetap dapat eksis dan mampu bertahan dalam persaingan.Pengusaha harus tetap mengembangkan usahanya pada bidang-bidang yang laku dipasar seperti pengolahan buah-buahan.

Salah satu bentuk usaha olahan buah-buahan yang terdapat di Kabupaten Wonosobo.Wonosobo adalah daerah dataran tinggi yang banyak menyediakan sumber kekayaan berupa buah-buahan seperti buah carica dan sayur-sayuran. .Dataran Dieng yang berada di Wonosobo merupakan suatu daerah yang memiliki kekayaan alam berlimpah diantaranya sayur-sayuran dan buah carica sebagai komoditas unggulan, dimana buah carica dapat tumbuh dan berbuah dengan baik. Kandungan vitamin yang terdapat dalam buah carica sangat bermanfaat untuk tubuh.

Dalam sebuah produksi di perlukan metode untuk menghitung biaya produksi seperti perhitungan yang sering digunakan adalah metode full costing yang menghitung seluruh biaya produksi baik variabel ataupun tetap, Variabel costing hanya menghitung biaya produksi bersifat variabel saja kepada suatu produk. Hasil perhitungan harga pokok produksi digunakan manajemen sebagai alat perencanaan laba serta mengambil keputusan penting lainnya.

Berdasarkan penelitian terdahulu yang dilakukan oleh Mukminatun (2016) yaitu tentang Analisis penentuan harga pokok dengan metode variabel costing pada barang jadi di Toko Family Kutowinangun, yang menyatakan bahwa dengan metode variabel costing dianggap lebih tepat untuk membantu pengambilan keputusan jangka pendek yang diperlukan oleh perusahaan

Pokok permasalahan penelitian adalah : "Bagaimana menganalisis perbandingan harga pokok produksi metode full costing dan variable costing pada CV Gemilang Kencana Wonosobo Tahun 2020?."

Tujuan penelitian yaitu untuk mengetahui dan menganalisis perhitungan harga pokok produksi metode full costing dan varibel costing di CV Gemilang Kencana tahun 2020.

\section{KAJIAN PUSTAKA}

Akuntansi biaya adalah proses pengidentifikasian, pencataan, penghitungan, peringkasan, pengevaluasian dan pelaporan biaya pokok suatu produk baik barang maupun jasa dengan metode dan sistem tertentu sehingga pihak manajemen perusahaan dapat mengambi keputusan secara efektif dan efisien.

Menurut Mulyadi (2016:7) Akuntansi biaya adalah proses pencatatan, penggolongan, peringkasan dan penyajian biaya, pembuatan dan penjualan produk atau jasa, dengan cara-cara tertentu, serta penafsiran terhadapnya. Obyek kegiatan akuntansi biaya adalah biaya.

Menurut Mulyadi (2016:8) Biaya dalam arti luas adalah pengorbanan sumber ekonomi, yang diukur dalam satuan uang, yang telah terjadi atau yang kemungkinan akan terjadi untuk tujuan tertentu.

Menurut V. Wiratna Sujarweni (2015:9) Biaya mempunyai dua pengertian yaitu pengertian secara luas dan secara sempit. Biaya dalam arti luas adalah pengorbanan sumber 
ekonomi yang diukur dalam satuan uang dalam usahanya untuk mendapatkan sesuatu untuk mencapai tujuan tertentu baik yang sudah terjadi dan belum terjadi atau baru direncanakan.Biaya dalam arti sempit adalah pengorbanan sumber ekonomi dalam satuan uang untuk memperoleh aktiva.

Menurut V.Wiratna Sujarweni (2015:10) Biaya yang terjadi di perusahaan perlu ditelusuri berasal dari mana saja biaya tersebut. Angka-angka yang disebut sebagai biaya dapat diklasifikasikan sebagai berikut :

a. Berdasarkan Pengelompokan Biaya

b. Biaya Pabrikase/Pabrik/Manufaktur

c. Bahan Baku

Adalah biaya yang dikeluarkan untuk membeli bahan baku utama yang dipakai untuk memproduksi barang.

a. Tenaga Kerja LangsungAdalah biaya yang dikeluarkan untuk membayar tenaga kerja utama yang langsung berhubungan dengan produk yang diproduksi dari bahan baku mentah menjadi barang jadi.

b. Biaya Overhead PabrikBiaya yang dikeluarkan untuk memproduksi barang, selain biaya bahan baku dan biaya tenaga kerja langsung.

Berdasarkan Perilaku Biaya Kalsifikasi biaya berdasarkan perilaku biaya dibagi menjadi empat (4) yaitu :

a. Biaya VariabeBiaya yang jumlahnya berubah-ubah, namun perubahannya sebanding dengan perubahan volume produksi/penjualan.

b. Biaya TetapBiaya yang tidak berubah jumlahnya walaupun jumlah yang diproduksi/dijual berubah dalam kapasitas normal.

c. Biaya Semi VariabelBiaya yang jumlahnya ada yang berubah-ubah sesuai dengan perubahan kuantitas di nada tarif tetapnya.

d. Biaya BertingkatBiaya yang dikeluarkan sifatnya tetap harus dikeluarkan dalam suatu rentang produksi.

Perhitungan Harga Pokok. Produksi Metode Full Costing Menurut Mulyadi (2016:122) menyatakan bahwaFull Costing atau sering pula disebut absorption atau conventional costing adalah metode penentuan harga pokok produksi, yang membebankan seluruh biaya produksi baik yang berperilaku tetap maupun variabel kepada produk. Harga pokok produksi menurut metode full costing terdiri dari :

$\begin{array}{ll}\text { Biaya bahan baku } & \mathrm{Rp} x \mathrm{x} \\ \text { Biaya tenaga kerja langsung } & \mathrm{Rp} x \mathrm{x} \\ \text { Biaya overhead pabrik tetap } & \mathrm{Rp} x \mathrm{x} \\ \text { Biaya overhead pabrik variabel } & \mathrm{Rp} x \mathrm{x} \\ \text { Harga pokok produksi } & \mathrm{Rp} x \mathrm{x}\end{array}$

Perhitungan Harga Pokok Produksi Metode Variabel Costing.Menurut Mulyadi (2016:122) Variabel Costing adalah metode penentuan harga pokok produksi yang hanya membebankan biaya-biaya produksi variabel saja ke dalam harga pokok produk. Harga pokok produk menurut metode variabel costing terdiri dari :

Biaya bahan baku $\quad \mathrm{Rp} x \mathrm{x}$ 
Biaya tenaga kerja langsung $\quad \mathrm{Rp} x \mathrm{x}$

Biaya overhead pabrik variable $\quad \mathrm{Rp} x \mathrm{x}$

Harga pokok produksi $\quad \mathrm{Rp} x \mathrm{x}$

Penyajian Laporan Rugi-Laba.Menurut Mulyadi (2016:125) menyatakan bahwa Metode full costing menitikberatkan pada penyajian unsur-unsur biaya menurut hubungan biaya dengan fungsi-fungsi pokok yang ada dalam perusahaan. Dengan demikian laporan rugi-laba metode full costing tampak seperti berikut :

\begin{tabular}{|c|c|}
\hline \multicolumn{2}{|c|}{$\begin{array}{ll}\text { Hasil Penjualan } & \text { Rp xxx } \\
\text { Harga Pokok Penjualan (termasuk BOP tetap) } & (\underline{\operatorname{Rp} x x x})\end{array}$} \\
\hline Laba Bruto & $\operatorname{Rp} x \times x$ \\
\hline Biaya Administrasi dan Umum & $\operatorname{Rp} x x x$ \\
\hline Biaya Pemasaran & $\underline{\mathrm{Rp}} \mathrm{xxx}$ \\
\hline Laba Bersih Usaha & Rp xxx \\
\hline
\end{tabular}

Gambar 2.1 : Laporan Rugi-Laba Full Costing Sumber : Mulyadi (2016:125)

Metode variabel costing lebih menitikberatkan pada penyajian biaya sesuai dengan perilakunya dalam hubungannya dengan perubahan volume kegiatan. Sehingga laporan ruglaba metode variabel costing tempak seperti berikut :

Hasil Penjualan

$\operatorname{Rp} x x x$

Biaya Variabel :

Biaya produksi variabel

$\operatorname{Rp} x x x$

Biaya pemasaran variabel

$\operatorname{Rp} \operatorname{xxx}$

Biaya administrasi\&umum vriabel

Rp $x x x$

Laba kontribus

$\operatorname{Rp} x x x$

Biaya Tetap :

Biaya produksi tetap

$\operatorname{Rp} x x x$

Biaya pemasaran tetap

$\operatorname{Rp} x x x$

Biaya administrasi\&umum tetap

$\operatorname{Rp} x x x$

Laba bersih usaha

$\operatorname{Rp} \operatorname{xxxx}$

\section{METODE}

\subsection{Metode Penelitian}

Metode penelitian ini adalah deskriptif dengan pendekatan kuantitatif dengan bertujuan untuk mendpatkan gambaran dan keterangan terhadap gejala tertentu dan menjelaskan 
hubungan antar variable berdasarkan fakta dengan cara melakukan pengumpulan dan analisis data berupa angka-angka.

\subsection{Definisi Operasional Variabel}

Definisi operasional penelitian adalah Harga pokok produksi sebagai variabel independen atau variabel bebas dan Metode Full costing dan variabel Costing sebagai variabel dependen atau variabel terikat.

\subsection{Teknik Pengumpulan Data}

Datadibagi menjadi data utama (prime) yang berupa biaya-biaya produksi di CV Gemilang Kencana dan data kedua (sekunder)di dapat dari sumber yang sudah ada. Teknikdata didapatdengan wawancara, observasi, Dokumentasi, dan Study Pustaka.

\subsection{Teknik Analisis Data}

Teknik analisis data yang digunakan:

a.

$$
\text { Perhitungan Full Costing }
$$

Analisis perhitungan ini terdiri dari :

$\begin{array}{ll}\text { Biaya untuk bahan baku Rp. } x & \text { R }\end{array}$

Biaya untuk tenaga kerja langsung $\quad \mathrm{x}$

Biaya untuk overheadpabrik- tetap $\quad \mathrm{x}$

Biaya untuk overheadpabrik - variabel $\quad \underline{\mathrm{x}}$

$\begin{array}{ll}\text { Harga pokok produksi } & \text { Rp. } x\end{array}$

b. Perhitungan Variabel Costing

Analisis perhitungan ini terdiri dari :

Biaya untuk bahan baku

Rp. $\mathrm{X}$

Biaya untuk tenaga kerja langsung

X

Biaya untuk overheadpabrik - tetap

$\mathrm{x}$

Biaya untuk overheadpabrik - variabel $\quad \underline{\mathrm{X}}$

Harga pokok produksi

$\operatorname{Rp} x$

\section{HASIL DAN PEMBAHASAN}

\subsection{Biaya-biaya yang Diperhitungkan Untuk Penentuan HargaPokok Produksi}

a. Biaya Bahan Baku

Unsur dari harga pokok produksimerupakan biaya untukbahan baku, biaya pemakaian bahan baku yaitu buah carica dan gula rafinasi karna dalam proses produksi manisan carica kedua bahan baku tersebut tidak bisa dipisahkan. Setiap bulan yang dikeluarkan untuk memperoleh bahan baku tersebut selama tahun 2020. Lihat table berikut ini : 
@Suratno $^{1^{*}}$, Wakhid Yuliyanto ${ }^{2}$

Tabel 3.1 Pemakaian Biaya dan Bahan Baku Buah Carica

\begin{tabular}{llccc}
\hline No & \multicolumn{1}{c}{ Bulan } & $\begin{array}{c}\text { Jumlah } \\
(\mathrm{Kg})\end{array}$ & $\begin{array}{c}\text { Harga } \\
(\mathrm{Kg})\end{array}$ & $\begin{array}{c}\text { Pemakaian } \\
(\mathrm{Rp})\end{array}$ \\
\hline 1 & Januari & 12.900 & 5.000 & 64.500 .000 \\
2 & Februari & 12.900 & 5.000 & 64.500 .000 \\
3 & Maret & 8.607 & 5.000 & 43.035 .000 \\
4 & April & 9.570 & 5.000 & 47.850 .000 \\
5 & Mei & 16.991 & 5.000 & 84.955 .000 \\
6 & Juni & 11.182 & 5.000 & 55.910 .000 \\
7 & Juli & 12.763 & 5.000 & 63.815 .000 \\
8 & Agustus & 13.426 & 5.000 & 67.130 .000 \\
9 & September & 6.990 & 5.000 & 34.950 .000 \\
10 & Oktober & 11.633 & 5.000 & 58.165 .000 \\
11 & November & 9.332 & 5.000 & 46.660 .000 \\
12 & Desember & 8.684 & 5.000 & 43.420 .000 \\
& Jumlah & 134.978 & & 674.890 .000 \\
\hline \multicolumn{5}{c}{ Sumber:CV Gemilang Kencana }
\end{tabular}

Tabel 3.2 Pemakaian Biaya Bahan Baku Gula Rafinasi

\begin{tabular}{lllrc}
\hline No & \multicolumn{1}{c}{ Bulan } & $\begin{array}{c}\text { Jumlah } \\
(\mathrm{Kg})\end{array}$ & $\begin{array}{c}\text { Harga } \\
(\mathrm{Kg})\end{array}$ & $\begin{array}{c}\text { Pemakaian } \\
(\mathrm{Rp})\end{array}$ \\
\hline 1 & Januari & 3.961 & 12.500 & 49.512 .500 \\
2 & Februari & 3.961 & 12.500 & 49.512 .500 \\
3 & Maret & 2.600 & 12.500 & 32.500 .000 \\
4 & April & 3.077 & 12.500 & 38.462 .500 \\
5 & Mei & 5.196 & 12.500 & 64.950 .000 \\
6 & Juni & 3.380 & 12.500 & 42.250 .000 \\
7 & Juli & 3.780 & 12.500 & 47.250 .000 \\
8 & Agustus & 3.871 & 12.500 & 48.387 .500 \\
9 & September & 2.234 & 12.500 & 27.925 .000 \\
10 & Oktober & 3.558 & 12.500 & 44.475 .000 \\
11 & November & 2.712 & 12.500 & 33.900 .000 \\
12 & Desember & 2.693 & 12.500 & 33.662 .500 \\
& Jumlah & 41.023 & & 512.787 .500 \\
\hline \multirow{3}{*}{} & & Sumber:CV Gemilang Kencana
\end{tabular}

Jumlah biaya pemakaian bahan baku selama tahun 2020 sebesar Rp 1.187.677.500,- yang dihasilkan dari menjumlahkan seluruh biaya bahan baku yang terdiri dari buah carica sebesar $\mathrm{Rp}$ 647.890.000 dan gula rafinasi sebesar $\mathrm{Rp} 512.787 .500$, dan dalam satu tahun menghabiskan 
134.978 Kg Buah Carica dengan harga per Kg Rp 5.000,- dan 41.023 Kg Gula rafinasi dengan harga per $\mathrm{Kg} \operatorname{Rp} 12.500,-$.

\section{b. Biaya Tenaga Kerja Langsung}

Perhitungan biaya untuk tenaga kerja langsung ditentukan dengan mengalikan jumlah tenaga kerja dan tariff upah yang telah ditetapkan, untuk tarif upah di CV Gemilang Kencana setiap karyawan berbeda-beda yaitu mulai dari Rp 30.000 sampai Rp 51.000 per orang dan dibayarkan setiap satu minggu sekali. Perhitungan seluruh biaya untuk tenaga kerja langsung untuk tahun 2020sebagai berikut

\begin{tabular}{cll}
\multicolumn{3}{c}{ Tabel 3.3 Biaya Tenaga Kerja Langsung } \\
\hline No & \multicolumn{1}{c}{ Bulan } & Jumlah (Rp.) \\
\hline 1 & Januari & 12.292 .000 \\
2 & Februari & 20.710 .500 \\
3 & Maret & 13.870 .000 \\
4 & April & 13.708 .500 \\
5 & Mei & 25.225 .000 \\
6 & Juni & 19.307 .000 \\
7 & Juli & 17.865 .000 \\
8 & Agustus & 21.265 .000 \\
9 & September & 12.903 .500 \\
10 & Oktober & 15.348 .500 \\
11 & November & 18.496 .000 \\
12 & Desember & 13.254 .500 \\
3 & JUMLAH & 204.275 .500 \\
\hline & Sumber: CV Gemilang Kencana
\end{tabular}

Biaya untuk tenaga kerja langsung tahun 2020 dengan total sebesar Rp. 204.275.500,untuk 19 orang.

\section{c. Biaya Overhead Pabrik}

Biaya overheadpabrik tahun 2020 : 
@Suratno $^{1^{*}}$, Wakhid Yuliyanto ${ }^{2}$

Tabel 3.4 Biaya Overhead Pabrik

\begin{tabular}{lr}
\hline \multicolumn{1}{c}{ Jenis Biaya } & Jumlah (Rp.) \\
\hline BiayaPenyusutanBangunan Pabrik & 125.000 .000 \\
Biaya Penyusutan Mesin Pabrik & 10.125 .000 \\
BiayaPenyusutanKendaraan Pabrik & 17.500 .000 \\
Biaya Penyusutan Peralatan Pabrik & 5.197 .250 \\
BiayaTenaga Kerja Tak Langsung & 216.000 .000 \\
Biaya Bahan Penolong & 256.937 .540 \\
Biaya Air dan Listrik & 5.548 .700 \\
Biaya Bensin/Akomodasi & 9.809 .500 \\
Biaya Perawatan Mesin & 1.005 .000 \\
Jumlah Biaya Overhead Pabrik & 647.122 .990 \\
\hline \multicolumn{2}{c}{ Sumber : CV Gemilang Kencana }
\end{tabular}

Berdasarkan data biaya-biaya di atas jumlah biaya overhead pabrik yang dikeluarkan pada tahun 2020 senilai Rp 647.122.990,- yang dihasilkan dari menjumlahkan seluruh biaya penyusutan aktiva tetap, tenaga kerja tidak langsung, bahan penolong, air dan listrik, bensin/akomodasi, perawatan mesin.

Dari data biaya overhead pabrik diatas maka perlu dilakukan pemisahan antara biaya overheadpabrik tetap dan biaya overhead pabrik variabel yang akan digunakan untuk menghitung harga pokok produksi berdasarkan data biaya-biaya di atas yang selanjutnya akan disajikan melalui table berikut ini :

Tabel 3.4 BiayaOverheadPabrik Tetap tahun 2020

\begin{tabular}{lccc}
\hline Jenis Biaya & & \multicolumn{1}{l}{ Jumlah (Rp.) } \\
\hline $\begin{array}{l}\text { Biaya Penyusutan } \\
\text { Pabrik }\end{array}$ & Aktiva & Tetap & .157 .822 .250 \\
$\begin{array}{l}\text { Biaya Tenaga } \\
\text { Langsung }\end{array}$ & & \\
Total BOP Tetap & Tak & .216 .000 .000 \\
\multicolumn{2}{c}{ Sumber: CV Gemilang Kencana }
\end{tabular}

Berdasarkan tabel di atas jumlahbiaya overhead pabrik tetap yang dikeluarkan pada tahun 2020 sebesar Rp. 373.822.250,- yang didapat dari menjumlahkan seluruh biaya penyusutan aktiva tetap dan biaya tenaga kerja tak langsung.

Tabel 3.4 BiayaOverheadPabrik Variabel tahun 2020

\begin{tabular}{ll}
\hline Jenis Biaya & Jumlah \\
\hline Biaya Bahan Penolong & Rp 256.937.540 \\
Biaya Air dan Listrik & Rp 5.548 .700
\end{tabular}


@Suratno $^{1^{*}}$, Wakhid Yuliyanto ${ }^{2}$

\begin{tabular}{llr} 
Biaya Bensin/Akomodasi & $\mathrm{Rp}$ & 9.809 .500 \\
Biaya Perawatan Mesin & $\mathrm{Rp}$ & 1.005 .000 \\
Total BOP Variabel & $\mathrm{Rp}$ & 273.300 .740 \\
\hline \multicolumn{2}{c}{ Sumber : CV Gemilang Kencana }
\end{tabular}

Berdasarkan tabel di atas jumlah biayaoverhead pabrik variableyang dikeluarkan pada tahun 2020 sebesar Rp. 273.300.740,- yang didapat dari menjumlahkan biaya bahan penolong, biaya air dan listrik, biaya bensin/akomodasi, dan biaya perawatan mesin.

\subsection{Perbandingan Perhitungan Harga Pokok Produksi Metode Full Costing dan Variabel Costing}

Rekapitulasi perhitungan harga pokok produksi setiap bulanuntuk tahun 2020 :

Tabel 3.19. Perbandingan HargaPokokProduksi 2 Metode

\begin{tabular}{lll}
\hline \multicolumn{1}{c}{ Bulan } & Full Costing & Variabel Costing \\
\hline Januari & Rp 186.919.105 & Rp 155.767.250 \\
Februari & Rp 188.242.305 & Rp 157.090.450 \\
Maret & Rp 136.929.230 & Rp 105.140.375 \\
April & Rp 153.695.080 & Rp 122.543.225 \\
Mei & Rp 232.764.205 & Rp 201.612.350 \\
Juni & Rp 173.701.305 & Rp 142.549.450 \\
Juli & Rp 187.897.630 & Rp 156.745.775 \\
Agustus & Rp 196.264.810 & Rp 165.112.965 \\
September & Rp 125.162.305 & Rp 94.010.450 \\
Oktober & Rp 176.110.680 & Rp 144.958.825 \\
November & Rp 157.567.005 & Rp 126.415.150 \\
Desember & Rp 154.459.330 & Rp 123.307.475 \\
Jumlah & Rp2.069.075.990 & Rp1.695.253.740 \\
\hline
\end{tabular}




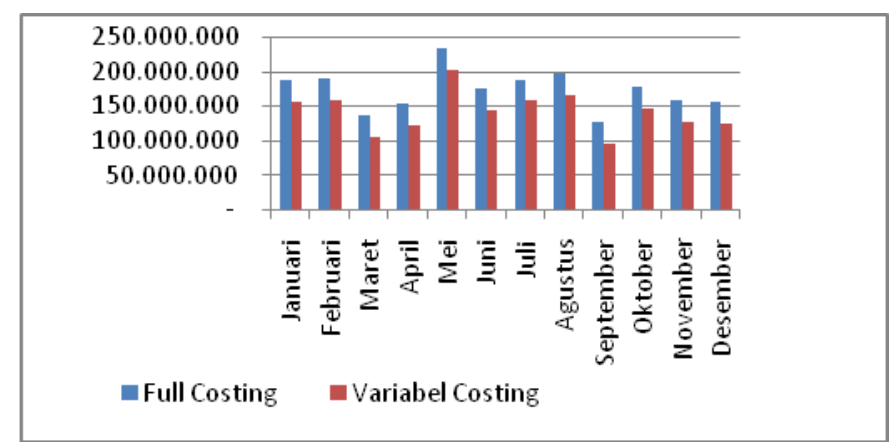

Gambar 3.3.Grafik Perbandingan Harga Pokok Produksi Sumber :Data Diolah

1. Perhitungan harga pokok produksi perkilogram full costing

Tabel 3.20 Perhitungan Harga Pokok Produksi Perkilogram Harga Pokok Produksi Rp 2.069.075.990

\begin{tabular}{lcc}
\hline Buah Carica & \multicolumn{3}{c}{$134.978 \mathrm{Kg}$} \\
\hline Harga Produksi/Kg & $\mathrm{Rp}$ & 15.329 \\
\multicolumn{3}{c}{ Sumber : Data Diolah }
\end{tabular}

2. Perhitungan harga pokok produksi perkilogram variabel costing

Tabel 3.21 Perhitungan Harga Pokok Produksi Perkilogram

\begin{tabular}{lcr} 
Harga Pokok Produksi & Rp 1.695 .253 .740 \\
\hline Buah Carica & & $134.978 \mathrm{Kg}$ \\
\hline Harga Produksi/Kg & $\mathrm{Rp}$ & 12.599 \\
\multicolumn{3}{c}{ Sumber : Data Diolah }
\end{tabular}

Dari table diatas dihasilkan perbandingan yang berbeda.Perhitungan full costing didapatkan hasil Rp. 2.069.075.990,-- sedangkan menggunakan perhitungan variabel costing didapatkan hasil sebesar Rp 1.695.253.740,- dan selisihnya sebessar Rp 373.822.250,-.Dan dilihat dari grafik untuk bulan mei mengalami penigkatan yang paling tinggi dan di bulan September yang paling rendah Sehingga jika dihitunga harga pokok produksi per Kg buah carica untuk full costing menghasilkan $\mathrm{Rp} 15.329$ per $\mathrm{Kg}$, dan untuk variabel costing menghasilkan Rp 12.599 per Kg. Perbedaan yang terjadi karenaadanya penggunaan metode perhitungan yang tidak sama.

\subsection{Masalah Yang Dihadapi}

1. Sumber daya manusia (SDM) masih kurang dalam pengetahuan akuntansi, dan ketersediaan bahan baku yang fluktuatif.

2. Bagian pemasaran belum bekerja maksimal.Belum ada pembukuan yang berkualitas, belum ada bagian accounting, belum ada perhitungan tentang produksi yang rinci 


\subsection{Solusi}

1. Memberikan pelatihan kepada karyawan dan membuat jadwal pembelian bahan baku juga cadangan produk setiap bulannya.

2. Dengan selalu melakukan breafing dan evaluasi kerja.

\section{KESIMPULAN}

\subsection{Kesimpulan}

1. Perhitungan dengan metode full costingmenghasilkan total harga pokok produksi sebesar Rp. 2.069.075.990 atau Rp. 15.329/Kg.

2. Perhitungan dengan metode variabel costingmenghasilkan total harga pokok produksi sebesar Rp. 1.695.253.740 atau Rp. 12.599/Kg.

3. Perbandingan perhitungan harga pokok dari kedua metode tersebut ternyata hasil metode full costing lebih besar daripada metode variabel costing denganselisih sebesar Rp.373.822.250 atauRp 2.730/Kg. .

\subsection{Saran}

1. Seharusnya pihak perusahaan membuat laporan keuangan agar dapat mengetahui posisi keuangan secara pasti sehingga dapat diketahui laba ruginya.

2. Sebaiknya mencari tenaga pembukuan yang mempunyai kompetensi yg baik.

\section{REFERENSI}

Halim, Abdul dkk.2011.Akuntansi Manajemen Edisi Kedua.Yogyakarta:BPFE

Mukminatun.2016. Analisis Penentuan Harga Pokok dengan Metode Variabel Costing pada Barang Jadi Di Toko Family Kutowinangun

Mulyadi.2016.Akuntansi Biaya Edisi Ke-5 Cetakan Sebelas.Unit Penerbit dan Percetakan Sekolah Tinggi Ilmu Manajemen YKPN:Yogyakarta

Sugiyono.2012.Metode Penelitian Kuantitatif Kualitatif dan R \& D. Bandung:Alfabeta

Sugiyono.2012.Metode Penelitian Kuantitatif, Kualitatif, dan Kombinasi (Mixed Methods).Bandung:Alfabeta

Sujarweni, Wiratma V.2015 Akuntansi Biaya Teori dan Penerapannya.Yogyakarta:Pustaka Baru Press

Suratno.2015.Modul Akuntansi Biaya:Kebumen

.http://www.google.com/amp/s/dosenakuntansi.com/harga-pokok-produksi/amp $\quad[$ Rabu, 15 April 2020, Pukul 10.15 WIB]

http://www.zonareferensi.cm/pengertian-observasi [Rabu, 08 April 2020, Pukul 17.15 WIB] 
http://www.BankKebumen.com/produk-layanan

[Rabu, 08 April 2020, Pukul 19.01 WIB]

M Darmowiyono, W Yuliyanto, KI Purnomo, W Marlini... - Journal of Physics: Conference Series, 2021 Application of the Simple Multi Attribute Rating Technique (SMART) Method in the selection of thrush medicine products based on consumershttps://iopscience.iop.org/article/10.1088/1742-6596/1783/1/012015/meta

E Aprilawati, W Yuliyanto - Jurnal E-Bis (Ekonomi-Bisnis), 2020Analisis Penyusunan Anggaran Dan Realisasinya Sebagai Alat Penilaian Kinerja Perusahaan Pada PT. Len Railway Systems (LRS) Kantor Cabang Kebumenhttps://jurnal.politeknikkebumen.ac.id/index.php/E-Bis/article/view/387 